ORIGINAL ARTICLE

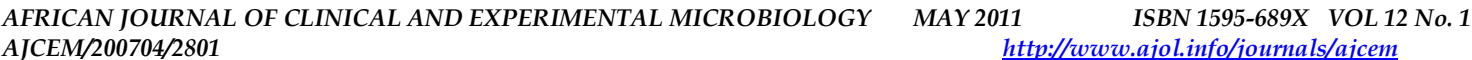

COPYRIGHT 2011

AFR. J. CLN. EXPER. MICROBIOL. 12(2): 86- 91

\title{
BACTERIOLOGICAL ANALYSIS OF WELL WATER SAMPLES IN SAGAMU.
}

\author{
A.O Idowu*, B.B Oluremi, K.M Odubawo
}

Department of Pharmaceutical Microbiology, Faculty of Pharmacy, Olabisi Onabanjo University, Ago-Iwoye, Nigeria. *Correspondence. E-mail: Solaid2002@yahoo.com. Tel: 08027348864, 07042261824

\begin{abstract}
S:
Majority of the population in semi-urban and urban areas of Nigeria depend on wells as their source of water supply. Due to increasing cases of water-borne diseases in recent times, this study was carried out to examine the microbial quality of well water in Sagamu, Nigeria as a way of safeguarding public health against water borne diseases. Water samples from a total of forty wells, covered and uncovered from four different locations of varying socio economic and demographic status were assessed for their bacteriological quality using serial dilution to obtain total bacteria count and the multiple tube fermentation technique to determine the coliform count using the most probable number method. Positive tubes of the presumptive test were further cultured on appropriate solid media. The organisms isolated were further characterized using standard procedures. The result of the study revealed that all the wells were grossly contaminated with bacteria pathogens such as Klebsiella spp (95\%), Escherichia coli (72\%) and Salmonella typhi $(32.5 \%)$. Comparatively, the uncovered wells were more highly contaminated with bacteria pathogens than the covered well especially in the highly populated areas. All the water samples exceeded the standard limit of the most probable number (MPN) per $100 \mathrm{ml}$ set for untreated drinking water. This result highlight the fact that most well water in Sagamu metropolis are not safe microbiologically for drinking without additional treatment such as boiling or disinfection and this could lead to outbreak of water borne diseases. Good and proper environmental and personal hygiene must be maintained especially by the users of those wells to prevent their contamination with bacterial pathogens.
\end{abstract}

Keywords:-Well water, bacteriological analysis, bacterial pathogens, water borne, diseases

\section{INTRODUCTION}

Water of good drinking quality is of basic importance to human physiology as well as indispensable to man's continued existence [1]. Its role as a medium of water borne disease which constitutes a significant percentage of the diseases that affect human and animals cannot be underestimated. This is the most important concern about the quality of water. Guideline for bacteriological water differs from country to country but they all conform to WHO recommendation. The standards for drinking water are more stringent than those for recreational waters. Availability of facilities and financial constraints are the major obstacles in the provision of water of good quality in developing countries and rural areas. In Nigeria, treated pipe borne water is limited to urban areas and the quantity provided inadequate and the frequency of supply epileptic. Such services may not even be available in certain areas within the metropolis. Due to this scenario, an increasing no of people in semi urban and urban areas in Nigeria including Sagamu depends on wells as their source of water supply. There has been increasing cases of food and water borne diseases in many parts of the country particularly typhoid fever and Cholera. There is a need therefore to have water supply surveillance as a way of keeping a careful watch at all times from the public health point of view, over the safety and acceptability of drinking water supplies [2]. In line with this, this study was conducted to investigate the bacterial content of well water that serve as the major source of drinking water in Sagamu, a semi urban area in Nigeria.

\section{MATERIALS AND METHODS}

\section{(A) STUDY AREA AND SAMPLING}

Water samples from forty wells from four different locations of varying socioeconomic and demographic status were randomly collected for bacteriological analysis. The areas are Isale Oko (Location W) Hospital Road (Location X), Station/GRA (Location Y) and Sabo (Location Z). Well water constitutes the major source of drinking water in these areas. Most of the wells under study were privately owned and are usually open to general public. Half of the numbers of the studied wells were covered while the others were not. Drawing of water from these wells was done by the use of 5-7 litre containers, which is tied directly to the well cover. In certain cases where this is not possible, individual fetcher usually comes with small bucket to draw water. The wells are not less than 10years old; 
some were constructed with concrete and are on average five meters deep.

\section{(B) COLLECTION OF WATER SAMPLES}

Water samples were collected in sterile bottle tied with a strong string to a piece of metal (about $500 \mathrm{~g})$ as the weight. The bottle cap was aseptically removed and the weighted bottle lowered into the well to a depth of about 1-2 meters. The bottle was brought up to a surface and covered with a screw cap when no air bubbles were seen inside.

\section{(C) BACTERIOLOGY}

Total bacterial count:- For each water sample, $1 \mathrm{ml}$ of a (1:100) dilution was inoculated into $19 \mathrm{ml}$ of molten nutrient agar, properly mixed and poured into a sterile Petri dish. The agar was allowed to set, and then incubated at $37^{\circ} \mathrm{C}$ for 24hours. The formed colonies were counted and result expressed as $\mathrm{cfu} / \mathrm{ml}$.

\section{PRESUMPTIVE COLIFORM TEST}

The multiple tube fermentation technique as described by Collins and Lynne [3] and Mackie and Mc cartney [4] was used. In this method, varying amounts of water sample were added to double and single strength Mac Conkey broth in bottles containing inverted sterile Durham tubes as follows.

- $1 \times 50 \mathrm{ml}$ of water to $50 \mathrm{ml}$ double strength medium

- $5 \times 10 \mathrm{ml}$ of water to $10 \mathrm{ml}$ double strength medium

- $5 \times 1 \mathrm{ml}$ of water to $5 \mathrm{ml}$ single strength medium

The bottles were incubated aerobically at $37^{\circ} \mathrm{C}$ for 18-24hours after which they were examined for production of acid and gas. Sterile distilled water was used as a control for each test batch.

Presumptive coliform count was obtained by the most probable number (MPN) of coliform per $100 \mathrm{ml}$ of water sample by making reference to the Mc Crady's probability table after combination of various positive and negative results

\section{(D) IDENTIFICATION OF ISOLATES}

Positive tubes of the presumptive test were subcultured on Mc Conkey agar for the enumeration of Escherichia coli and other enteric coliforms. Salmonella typhi and Shigella spp were enumerated using Salmonella Shigella agar and Triple Sugar Iron agar (TSI). All the inoculated media were incubated aerobically at $37^{\circ} \mathrm{C}$ for 24 hours, after which the isolates were further characterized by a combination of colonial and morphological characteristic on solid media as well as standard biochemical tests as described by Cowan and Steel [5]

\section{RESULTS:}

The total viable bacterial counts obtained are shown in Table 1. The value obtained from the well water samples ranged from $0.1-6.5 \times 10^{4}$ $\mathrm{cfu} / \mathrm{ml}$. The total viable bacterial counts obtained from uncovered wells $1.1-6.5 \times 10^{4} \mathrm{cfu} / \mathrm{ml}$ were higher than the values obtained from covered well $\left(0.1-2.8 \times 10^{4} \mathrm{cfu} / \mathrm{ml}\right)$. The values of the total viable bacterial count were lower in the 2 categories of wells studied in location $Y$ than in the other three locations.

Table 1: TOTAL BACTERIA VIABLE COUNT FROM WELL WATER SAMPLES IN SAGAMU

\begin{tabular}{|c|c|c|c|c|}
\hline & \multicolumn{5}{|l|}{ TOTAL BACTERIAL VIABLE COUNTS CFU/MLX10 } & Z \\
\hline SAMPLES & W & X & Y & 1.6 \\
\hline C1 & 2.0 & 1.2 & 0.4 & 0.8 \\
\hline C2 & 1.9 & 0.9 & 0.2 & 1.3 \\
\hline C3 & 2.4 & 1.6 & 0.6 & 1.2 \\
\hline C4 & 1.7 & 1.9 & 0.1 & 2.1 \\
\hline U1 & 2.8 & 1.4 & 0.3 & 5.2 \\
\hline U2 & 3.5 & 2.8 & 2.1 & 2.5 \\
\hline U3 & 2.9 & 2.1 & 1.9 & 4.7 \\
\hline U4 & 4.3 & 3.3 & 1.3 & 4.2 \\
\hline
\end{tabular}


Table 2: PRESUMPTIVE COLIFORM COUNT FROM WELL WATER SAMPLE IN SAGAMU

\begin{tabular}{|c|c|c|c|c|c|c|c|c|c|c|c|c|c|c|c|c|c|}
\hline \multirow[b]{3}{*}{ Samples } & \multirow{3}{*}{$\begin{array}{l}\text { Location } \\
\text { Quantity of } \\
\text { water } \\
\text { Numbers of } \\
\text { sample of each } \\
\text { quantity tested }\end{array}$} & \multicolumn{4}{|c|}{$\mathbf{W}$} & \multicolumn{4}{|l|}{$\bar{X}$} & \multicolumn{4}{|l|}{$\mathbf{Y}$} & \multicolumn{4}{|l|}{$\mathrm{Z}$} \\
\hline & & \multicolumn{4}{|c|}{$50 \mathrm{ml} 10 \mathrm{ml} 1 \mathrm{ml} \quad$ MPN } & & \multicolumn{3}{|c|}{ 10ml 1ml MPN } & \multicolumn{4}{|c|}{$50 \mathrm{ml} \mathrm{10ml} 1 \mathrm{ml}$ MPN } & \multicolumn{4}{|c|}{$50 \mathrm{ml} 10 \mathrm{ml} 1 \mathrm{ml}$ MPN } \\
\hline & & 1 & 5 & 5 & & 1 & 5 & 5 & & 1 & 5 & 5 & & 1 & 5 & 5 & \\
\hline C1 & \multirow{10}{*}{$\begin{array}{l}\text { NUMBER } \\
\text { GIVING } \\
\text { POSITIVE } \\
\text { REACTION } \\
\text { (ACID AND } \\
\text { GAS) }\end{array}$} & 1 & 5 & 4 & 160 & 1 & 5 & 4 & 160 & 1 & 4 & 3 & 30 & 1 & 5 & 4 & 160 \\
\hline $\mathrm{C} 2$ & & 1 & 5 & 3 & 90 & 1 & 5 & 2 & 50 & 1 & 4 & 5 & 40 & 1 & 5 & 3 & 90 \\
\hline C3 & & 1 & 5 & 2 & 50 & 1 & 5 & 3 & 90 & 1 & 5 & 2 & 50 & 1 & 5 & 4 & 160 \\
\hline C4 & & 1 & 5 & 4 & 160 & 1 & 4 & 5 & 40 & 1 & 4 & 4 & 35 & 1 & 5 & 4 & 160 \\
\hline C5 & & 1 & 5 & 3 & 90 & 1 & 5 & 3 & 90 & 1 & 5 & 3 & 90 & 1 & 5 & 3 & 90 \\
\hline U1 & & 1 & 5 & 5 & $180^{+}$ & 1 & 5 & 5 & $180^{+}$ & 1 & 5 & 4 & 160 & 1 & 5 & 5 & $180^{+}$ \\
\hline U2 & & 1 & 5 & 5 & $180^{+}$ & 1 & 5 & 4 & 160 & 1 & 5 & 4 & 160 & 1 & 5 & 5 & $180^{+}$ \\
\hline U3 & & 1 & 5 & 5 & $180^{+}$ & 1 & 5 & 5 & $180^{+}$ & 1 & 5 & 4 & 160 & 1 & 5 & 5 & $180^{+}$ \\
\hline U4 & & 1 & 5 & 5 & $180^{+}$ & 1 & 5 & 4 & 160 & 1 & 5 & 5 & $180^{+}$ & 1 & 5 & 5 & $180^{+}$ \\
\hline U5 & & 1 & 5 & 5 & $180^{+}$ & 1 & 5 & 5 & $180^{+}$ & 1 & 5 & 4 & 160 & 1 & 5 & 5 & $180^{+}$ \\
\hline
\end{tabular}

Table 3: DISTRIBUTION OF BACTERIAL PATHOGEN ISOLATED FROM WATER SAMPLES IN SAGAMU

\begin{tabular}{|c|c|c|c|c|c|}
\hline & & \multicolumn{4}{|c|}{ IDENTIFIED ISOLATES } \\
\hline SAMPLES & LOCATION & $\mathbf{W}$ & $\bar{X}$ & $\bar{Y}$ & $\mathbf{Z}$ \\
\hline C1 & & $\begin{array}{c}\text { Escherichia coli, } \\
\text { Klebsiella spp }\end{array}$ & Klebsiella spp & Klebsiella spp & $\begin{array}{c}\text { Escherichia coli, } \\
\text { Klebsiella spp }\end{array}$ \\
\hline $\mathrm{C} 2$ & & $\begin{array}{c}\text { Escherichia coli, } \\
\text { Klebsiella spp }\end{array}$ & Klebsiella spp & Klebsiella spp & $\begin{array}{c}\text { Escherichia coli, } \\
\text { Klebsiella spp }\end{array}$ \\
\hline C3 & & $\begin{array}{c}\text { Escherichia coli, } \\
\text { Klebsiella spp }\end{array}$ & $\begin{array}{c}\text { Escherichia coli, } \\
\text { Klebsiella spp }\end{array}$ & Klebsiella spp & $\begin{array}{c}\text { Escherichia coli, } \\
\text { Klebsiella spp }\end{array}$ \\
\hline $\mathrm{C} 4$ & & $\begin{array}{c}\text { Escherichia coli, } \\
\text { Klebsiella spp }\end{array}$ & $\begin{array}{c}\text { Escherichia coli, } \\
\text { Klebsiella spp }\end{array}$ & Klebsiella spp & $\begin{array}{c}\text { Escherichia coli, } \\
\text { Klebsiella spp }\end{array}$ \\
\hline $\mathrm{C} 5$ & & $\begin{array}{c}\text { Escherichia coli, } \\
\text { Klebsiella spp }\end{array}$ & $\begin{array}{c}\text { Escherichia coli, } \\
\text { Klebsiella spp }\end{array}$ & Klebsiella spp & $\begin{array}{c}\text { Escherichia coli, } \\
\text { Klebsiella spp }\end{array}$ \\
\hline U1 & & $\begin{array}{l}\text { Escherichia coli, } \\
\text { Klebsiella spp, } \\
\text { Salmonella typhi }\end{array}$ & $\begin{array}{l}\text { Escherichia coli, } \\
\text { Klebsiella spp, } \\
\text { Salmonella typhi }\end{array}$ & $\begin{array}{l}\text { Escherichia coli, } \\
\text { Klebsiella spp }\end{array}$ & $\begin{array}{l}\text { Escherichia coli, } \\
\text { Klebsiella spp, } \\
\text { Salmonella typhi }\end{array}$ \\
\hline $\mathrm{U} 2$ & & $\begin{array}{c}\text { Escherichia coli, } \\
\text { Klebsiella spp }\end{array}$ & $\begin{array}{l}\text { Escherichia coli, } \\
\text { Klebsiella spp, } \\
\text { Salmonella typhi }\end{array}$ & Escherichia coli & $\begin{array}{l}\text { Escherichia coli, } \\
\text { Klebsiella spp, } \\
\text { Salmonella typhi }\end{array}$ \\
\hline U3 & & $\begin{array}{l}\text { Escherichia coli, } \\
\text { Klebsiella spp, } \\
\text { Salmonella typhi }\end{array}$ & $\begin{array}{l}\text { Escherichia coli, } \\
\text { Klebsiella spp, } \\
\text { Salmonella typhi }\end{array}$ & Klebsiella spp & $\begin{array}{l}\text { Escherichia coli, } \\
\text { Klebsiella spp, } \\
\text { Salmonella typhi }\end{array}$ \\
\hline $\mathrm{U4}$ & & $\begin{array}{l}\text { Escherichia coli, } \\
\text { Klebsiella spp, } \\
\text { Salmonella typhi }\end{array}$ & $\begin{array}{l}\text { Escherichia coli, } \\
\text { Klebsiella spp, } \\
\text { Salmonella typhi }\end{array}$ & Escherichia coli & $\begin{array}{l}\text { Escherichia coli, } \\
\text { Klebsiella spp, } \\
\text { Salmonella typhi }\end{array}$ \\
\hline U5 & & $\begin{array}{c}\text { Escherichia coli, } \\
\text { Klebsiella spp }\end{array}$ & $\begin{array}{l}\text { Escherichia coli, } \\
\text { Klebsiella spp, } \\
\text { Salmonella typhi }\end{array}$ & Klebsiella $s p p$ & $\begin{array}{l}\text { Escherichia coli, } \\
\text { Klebsiella spp, } \\
\text { Salmonella typhi }\end{array}$ \\
\hline
\end{tabular}

For tables 1-3

Key: C1 - C5 are water samples from covered wells

U1 - U5 are water samples from uncovered wells

Location W- Isale Oko area

Location $X$ - Hospital road area

Location $Y$ - Station/GRA area

Location $\mathrm{Z}$ - Sabo area

The presumptive coliform count measured by the most probable no per $100 \mathrm{ml}$ in the multiple tube fermentation technique of bacterial enumeration from the covered and uncovered well water samples from the different locations are indicated in Table 2. The most probable number MPN per $100 \mathrm{ml}$ for the well water sample ranged between

20 and $180^{+}$which clearly exceeded the standard limit set by the World Health Organization (WHO). Table 3 showed bacterial pathogens isolated from well water from different locations. Thirty five $(87.5 \%)$ well water samples from the tested locations were with two or more species of bacterial pathogen. 


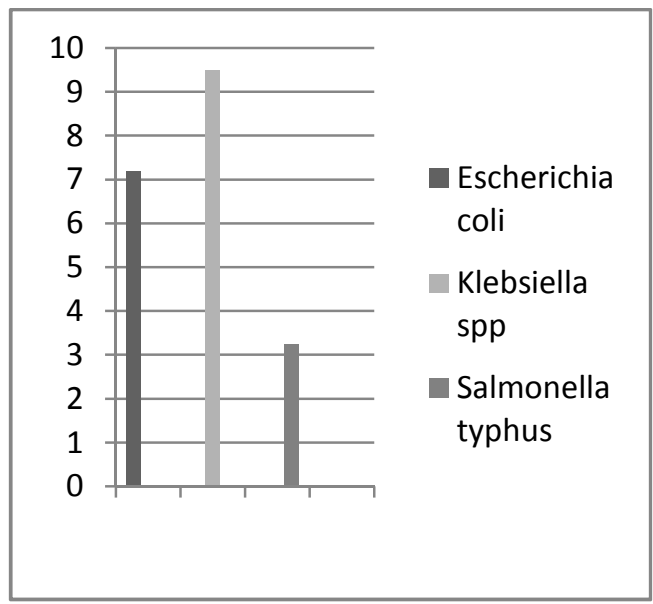

FIGURE 2: BAR CHART SHOWING DISTRIBUTION OF ORGANISMS AT VARIOUS LOCATIONS

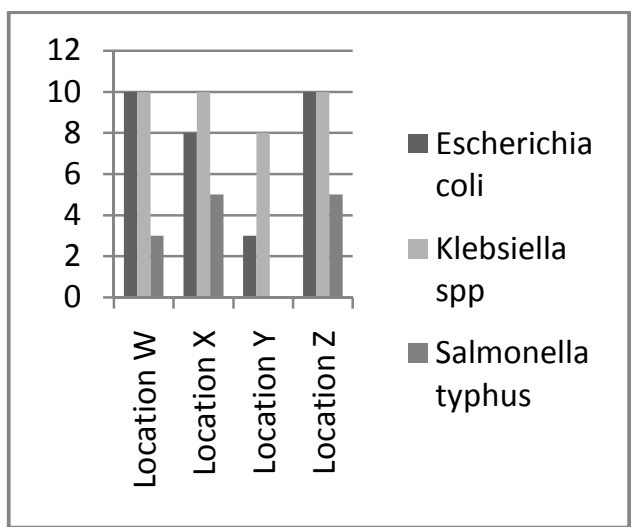

Klebsiella spp was the most predominant (95\%) in the well water samples, followed by Escherichia coli $(72 \%)$ and Salmonella typhi $(32.5 \%)$ fig 1 . The distribution of organism at the different locations varies as shown in Fig 2. Salmonella typhi was absent in water samples from location Y. The distribution of organisms in covered and uncovered wells samples (Fig 3 and Fig 4) showed that Salmonella typhi was only encountered in samples from uncovered wells.

\section{DISCUSSION}

The spread of diseases through faecal contamination of water sources particularly in developing and underdeveloped countries are a common phenomenon that has been well reported [2, 6, 8, 9]. In Ogun state as well as most part of Nigeria, availability of treated pipe-borne

\section{FIGURE 3: BAR CHART SHOWING DISTRIBUTION OF ORGANISMS FROM COVERED WELL AT DIFFERENT LOCATIONS}

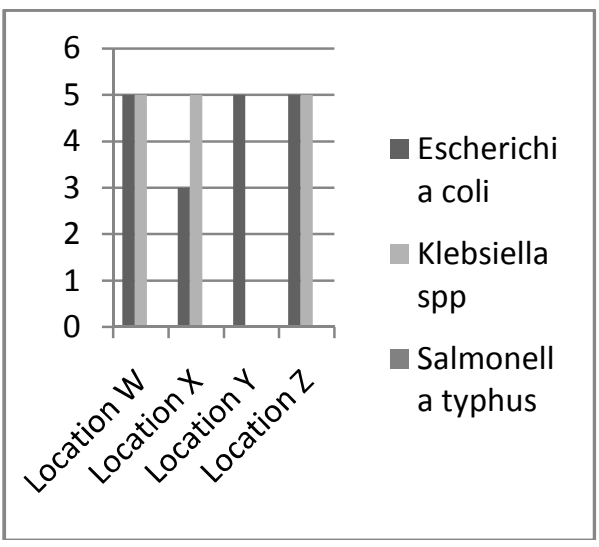

\section{FIGURE 4: BAR CHART SHOWING DISTRIBUTION OF ORGANISMS FROM UNCOVERED WELLS AT DIFFERENT LOCATIONS}

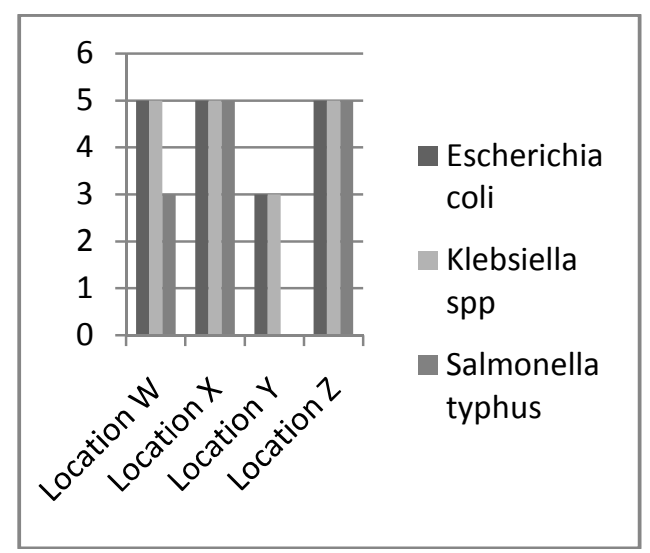

water is rare and restricted where it exist to urban and semi-urban areas. Even in these areas, public water supply is quite irregular. Consequently rich individuals dig boreholes as alternative water sources. The poor or average classes which constitute more than $80 \%$ of the population which cannot afford the high cost of borehole drilling are forced to dig wells as alternative source of water supply for drinking and sanitary purpose.

The viable bacterial count which is a measure of the microbial load of the water sample obtained in this study $\left(0.1-6.5 \times 10^{4} \mathrm{cru} / \mathrm{ml}\right)$ exceeded the recommended limit. This shows that the wells contain too high level of microbial contaminant that make water obtained from them a threat to public health.

The values obtained for the samples from the uncovered well were higher than the ones from 
the covered well. This is expected possibly due to the openness of the wells which permit unhindered access of particles from the surroundings compared to the covered wells.

It was observed that location $Y$ is a low population density area inhabited by people of high socioeconomic status where there might be better sanitation practices. Both categories of wells from this location recorded a lower microbial count than the other three locations. This indicates that better environmental condition as well as reduce pressure of use may reduce the degree of contamination that may be encountered in well water samples. However, the sanitary quality of potable water is determined primarily by the kinds of micro-organisms present rather than by the microbial count per see [10]

The most probable number (MPN) per $100 \mathrm{ml}$ obtained for the well water samples $\left(20-180^{+}\right)$ clearly exceeded standard limit set by WHO. This suggest that the well water samples have been contaminated by potentially dangerous microorganism and is therefore not fit for drinking purposes. This was confirmed by the characterization of the isolates from the well water samples from the locations under study which were highly contaminated with one or more bacterial pathogens namely Escherichia coli, Klebsiella spp and Salmonella typhi. The most predominant is the enteric coli form Klebsiella spp (95\%) followed by Escherichia coli (87.5\%) and Salmonella typhi (32.5\%).

These are pathogenic organisms mainly of faecal origin. Any water source used for drinking or cleaning purpose should not contain any organism of faecal origin [10,12]Presence of enteric coliforms especially Escherichia coli makes the water samples unsuitable for human consumption according to the guidelines set by WHO for the evaluation of bacteriological quality of drinking water [2]

Curiously, Salmonella typhi which was encountered only in the uncovered wells was not isolated from any of the water samples in location Y. This may not be unconnected with good and proper household hygiene envisaged in this area because of the calibre of people living in this area as well as absence of overcrowding which is the case in other locations under study. Apart from environmental hygiene and population density, the presence of Salmonella typhi in some of the uncovered wells in those areas may also be attributed to drainage and flooding from contaminated surface water into unprotected well shafts. Findings from this study clearly highlight the non conformity of well water samples studied with the WHO standard recommendation for safe potable water [8], a guideline being adopted by the NAFDAC.

This study corroborates earlier studies in Lagos and Ibadan where it was discovered that well water used as source of water for drinking and cleaning purposes were grossly contaminated with pathogenic organisms [13, 14] A situation where enteric pathogens are grossly isolated from sources of water consumed by humans is a serious problem which calls for vigilance on the part of the authorities as it signals possible future outbreak of water borne diseases. Such disease outbreak may spread widely within the country and even possibly extend to neighboring countries since Nigeria shares boundaries with many West African states.

The reason for the gross contamination of well waters by pathogens as observed in this study may be due to openness and shallowness of the wells which allows easy entrance of particles from the surroundings. It may also be due to poor sanitary condition around the areas where such wells are located or drawing water from the wells with contaminated containers, a practice that is common among the users since individuals bring along their own water containers.

The high morbidity that is recorded from enteric diseases such as diarrhea, dysentery and typhoid fever in the country may be due to widespread consumption of contaminated well water.

\section{CONCLUSION}

This study has shown that there is a high incidence of contamination of well waters by pathogenic organisms. To reduce the widespread incidence of contamination of well water, it is advocated that wells dug must be deep and covered adequately. Also good and proper personal and environmental sanitary practices must be maintained in and around the wells. Boiling well water before being used for drinking purposes would also go a long way to prevent incidence of waterborne diseases.

REFERENCES
Lamikanra A, (1999): Essential
Microbiology for students and
practitioners of Pharmacy,
Medicine and Microbiology 2nd
edition. Amkra Books, (2)
World Health Organization
(1996): Guidelines for Drinking


Water Quality: Health Criteria and other support information. 2: 18-97

(3)

Collins CR and Lynes PM (1976).Microbiology Method $4^{\text {th }}$ edition Butterworth press, London pp 271-275.

(4) Mackie T J and McCartney J E: (1989) Practical Medical Microbiology. Edited by College J C, Dugluid J P, Frasor A G and Marmion B P. Church Living Stone publication. 2: $910 \mathrm{pp}$.

(5) Cowan S T Steel S: (1993) Manual for identification of medical bacterial. Edition by Barrow G I, Feltham R KA. Cambridge University. 32

(6) Enujiugha VN. Balogh E and Oluwole AF. (1994) Occurrence of pathogens in two public water distribution systems in Western Nigeria. Nig. Food J. 12: 74-84.

(7)

World Health Organization (1997): Guideline for Drinking Water Quality: Surveillance and Control of Community Supplies. 3: 4-16, 96-219.

(8) Le-chevalier MW, Cawthon CD and Lee RG (1987). Factors promoting survival of bacteria in chlorinated water supplies. Applied Environmental Microbiol; 88: 649554.
(9)

Olowe O.A et al (2005).Bacteriological quality of water samples in Osogbo metropolis.Afr. J. of Clin. and Experimental Microbiol.6 (3):219222

(10) Bonde GJ. (1977) Bacterial indication of water pollution in advances in Aquatic microbiology, Academic press, London.

(11) Sabongari A. Drinking Water Quality. Proc. of the third Nat. conf. on water pollution, Port Harcourt, Nigeria pp 100-109

(12) Akeredolu FA (1991). Setting water Quality Standards for Nigeria. Proc. of first National conf. on water Quality Monitoring and status in Nigeria, (Kaduna pp 216-224)

(13) Adeyemo, O. K., Ayodeji, I. O. and Aiki-Raji, C. O (2002). The water quality and sanitary condition in a major abattoir (Bodija) in Ibadan, Nigeria. Afri. J. of Biomed. Resear. 5(1-2):51-55.

(14) Akinyemi, O.K, Oyefolu.A.O.B, Salu O.B, Adewale O.A and Fasure A.K. (2006).Bacterial associated with Tap and well waters in Lagos, Nigeria.East and Central Afri. J. of surgery.2 (1):110-117. 